\title{
Riboflavin Enhanced Denitrification of Artificial Wastewater under Low C/N Condition in Cold Season
}

\author{
Jingya Liu, ${ }^{\mathrm{a}}$ Jingang Huang, ${ }^{\mathrm{a}, \mathrm{b}, *}$ Binfang Shi, ${ }^{\mathrm{a}}$ Kangyin Guo, ${ }^{\mathrm{a}} \mathrm{Jianping} \mathrm{Li},{ }^{\mathrm{b}, *}$ and \\ Junhong Tang ${ }^{\mathrm{a}}$
}

\begin{abstract}
Nitrogen removal under low $\mathrm{C} / \mathrm{N}$ ratio in cold season is an arduous task. In this study, riboflavin was used as an eco-friendly electron mediator to improve the denitrification process in an SBR reactor under conditions of low temperature $\left(10^{\circ} \mathrm{C}\right.$ to $\left.15^{\circ} \mathrm{C}\right)$ and limited carbon source $(\mathrm{C} / \mathrm{N}$ ratio $=$ 4.0). The results indicated that riboflavin created a suitable $\mathrm{pH}$ in the system for denitrification. Under water temperature of $10^{\circ} \mathrm{C}$ to $15^{\circ} \mathrm{C}$, riboflavin (10 mg/L) stimulated the $\mathrm{NO}_{3}-\mathrm{N}$ and $\mathrm{TN}$ removal rate by $16.5 \%$, and $51 \%$, respectively. Riboflavin promoted the utilization efficiency of limited carbon source, driving the denitrification process with low residual acetate as electron donor. The rising cost of riboflavin supplement (10 $\mathrm{mg} / \mathrm{L}$ ) was 0.025 USD per $\mathrm{m}^{3}$ of wastewater. To satisfy the efficient nitrogen removal from municipal wastewater, the optimum $\mathrm{C} / \mathrm{N}$ ratio and the selection of solid/immobilized redox mediators should be developed in future work.
\end{abstract}

Keywords: Riboflavin; Denitrification; Cold; Carbon source; Nitrogen removal

Contact information: a: College of Materials and Environmental Science, Hangzhou Dianzi University, Hangzhou 310018, PR China; b: College of Biosystems Engineering and Food Science, Zhejiang University, Hangzhou 310058, PR China; *Corresponding authors: hjg@hdu.edu.cn; jpli@zju.edu.cn

\section{INTRODUCTION}

The combined process of nitrification-denitrification is a traditional but very effective method for nitrogen removal from municipal wastewater. Denitrification is affected by available carbon source, temperature, $\mathrm{pH}$, and dissolved oxygen (Elefsiniotis and $\mathrm{Li}$ 2006). In China, municipal wastewater is characterized by low $\mathrm{C} / \mathrm{N}$ ratio $(<6.0)$, meaning that low energy metabolism drives the biological redox-reaction of $\mathrm{NO}_{3}{ }^{-} \mathrm{N}$ to $\mathrm{NO}_{2}^{-}-\mathrm{N}$, and finally to $\mathrm{N}_{2}$ (Liang et al. 2014). In addition, water temperature below $15^{\circ} \mathrm{C}$ reduces or even ceases the microbial/enzymatic activity, decelerating the denitrification process (Ge et al. 2012). These problems urge the development of a cost-effective method to achieve high and quick nitrogen removal from wastewater with low $\mathrm{C} / \mathrm{N}$ ratio in cold seasons.

To facilitate nitrogen removal, the external addition of carbon sources such as methanol, sodium acetate, glucose, and other bio-available organic wastes are applied to drive the denitrification process (Zhang et al. 2019; Mielcarek et al. 2020). Reducing reagents such as zero valent iron $\left(\mathrm{Fe}^{0}\right)$, sulfide $\left(\mathrm{S}^{2-}\right)$, and hydrogen $\left(\mathrm{H}_{2}\right)$ are also inorganic electron donors (Oh et al. 2016; Zhang et al. 2019). However, this process consumes industrial resources and raises operating fees. Electron mediators can be applied to lower the activation energy $\left(E_{\mathrm{a}}\right)$, which enhances the denitrification rate and the utilization of limited carbon sources under low $\mathrm{C} / \mathrm{N}$ ratio (Guo et al. 2015). The standard redox potential $\left(E_{0}{ }^{\prime}\right)$ of a possible electron mediator should be between the two half reactions of donor- 
oxidation and denitrification, improving the extracellular electron transport (Van der Zee and Cervantes 2009). Artificial quinoid redox mediators, including anthraquinone (AQ), anthraquinone-2,6-disulphonate (AQDS), 2-hydroxy-1,4-naphthoquinone (LAW), and 1,2-naphthoquinone-4-sulphonate (NQS) can be reversibly transferred between their hydroquinone forms, shuttling electrons from the donor to nitrate and nitrite (Yuan et al. 2017). However, these quinone-associated artificial electron mediators are quite expensive, and they pose potential toxicity to the functional microbe and environment. Cadena Ramírez et al. (2019) reported an inhibitory effect of quinoid redox mediators on denitrification. In recent years, natural or eco-friendly redox mediators, e.g., chlorophyll and biochar, have been used for promoting denitrification (Wu et al. 2019; Lu et al. 2020).

Riboflavin is a biogenic product with electron mediating ability. Although many microorganisms could generate crude riboflavin, its production is very small. Thus, commercial riboflavin was served by chemical synthesis for a long time during the last century. Currently, crude riboflavin could be efficiently fermented by Bacillus subtilis and Ashbya gossypii strains with ordinary carbon sources such as vegetable oils (Revuelta et al. 2017). In comparison to chemical synthesis, biogenic production has its advantage in reducing the cost and the secondary pollution. Riboflavin is a relatively economical and available choice as an external electron mediator. It could eco-friendly improve the electron transport ability and shift the abundance of denitrifying bacteria (Guo et al. 2019). However, other studies reported that riboflavin could not benefit the isolation of denitrifier due to the high $\mathrm{C} / \mathrm{N}$ ratio (20) at $37{ }^{\circ} \mathrm{C}$ (Heylen et al. 2006). Under conditions of low $\mathrm{C} / \mathrm{N}$ ratio in cold seasons, the effect of riboflavin on denitrification process has not received enough research attention. This study aims to improve the nitrogen removal rate under low temperature and to maximize the utilization of limited carbon sources. The feasibility and future works of using riboflavin to upgrade the denitrification with low $\mathrm{C} / \mathrm{N}$ in cold seasons are considered.

\section{EXPERIMENTAL}

\section{Influent, Bioreactors, and Inoculum}

Artificial wastewater in this study was prepared with analytical grade potassium nitrate $\left(\mathrm{KNO}_{3}\right)$ and sodium acetate $\left(\mathrm{CH}_{3} \mathrm{COONa}\right)$. Riboflavin was purchased from Sinopharm Chemical Reagent Co., Ltd. (Shanghai, China). It was dissolved in alkaline conditions to a stock concentration of $18.8 \mathrm{~g} / \mathrm{L}$. Influent $\mathrm{C} / \mathrm{N}$ ratio was fixed at 4.0 , with $\mathrm{NO}_{3}{ }^{-} \mathrm{N}$ of $75 \mathrm{mg} / \mathrm{L}$, and sodium acetate of $384 \mathrm{mg} / \mathrm{L}$ because its COD equivalent was 0.78 . $\mathrm{NaHCO}_{3}$ buffer in the influent was supplied at $500 \mathrm{mg} / \mathrm{L} . \mathrm{Ca}, \mathrm{Mg}, \mathrm{Fe}$, and trace metals ( $\mathrm{Mn}, \mathrm{Zn}, \mathrm{Ni}, \mathrm{Co}$ ) were supplemented as described in a previous study (Huang et al. 2020). A plexiglass-made sequential batch reactor (SBR, 5L) was operated for two months in winter to examine the effect of riboflavin on nitrogen removal in the cold season. The inoculum was the returned activated sludge from a secondary clarifier of Qige Municipal Wastewater Treatment Plant (MWTP) in Hangzhou, China. The sludge in the SBR was 3 g VSS/L.

\section{SBR Operation}

The SBR was continuously operated in winter season for 61 days from Nov. 2017 to Jan. 2018, with two batches per day. The working procedure in each batch was as follows, 30 min feeding with a peristaltic pump, $10 \mathrm{~h}$ stirring (100 rpm) with a mechanical 
stirrer, $1 \mathrm{~h}$ gravity settling, and 30 min draining. No air was aerated during any operation. Despite the lack of aeration, dissolved oxygen (DO) in the initial $1 \mathrm{~h}$ was up to $1.8 \mathrm{mg} / \mathrm{L}$, due to the residual DO in the artificial wastewater. After that, DO in the SBR decreased to anoxic condition $(<0.5 \mathrm{mg} / \mathrm{L})$.

The total hydraulic retention time (HRT) was designed at $10.71 \mathrm{~h}$, and sludge retention time (SRT) was at 40 days. The entire operation was defined for three ongoing stages, i.e., Stage I (Denitrification acclimatization, Days 1 to 22), Stage II (Operating stabilization, Days 23 to 48), and Stage III (Riboflavin responding, Days 49 to 61). During the stages, different operational conditions were conducted to elucidate the effect of riboflavin on denitrification. Stages I and II were conducted with riboflavin-free influent. And the water temperature during Stage I was usually above $15^{\circ} \mathrm{C}$. After that, the water temperature decreased below $15{ }^{\circ} \mathrm{C}$. In Stage III, riboflavin $(10 \mathrm{mg} / \mathrm{L})$ was added to the influent to assess the advantage of riboflavin on nitrogen removal under low temperature. During the 61-day operation period, the effluent samples were collected every one or two days, for the analysis of various nitrogen species and chemical oxygen demand (COD).

\section{Chemical Analysis}

The $\mathrm{pH}$ and temperature were detected in situ using a portable $\mathrm{pH}$ meter (Mettler Toledo, F2 Standard, Greifensee, Switzerland). DO was detected by a portable DO meter (SANXIN, SX716, Shanghai, China). The collected samples were centrifuged at $4000 \times g$ and then filtered through disposable syringe filters $(0.45 \mu \mathrm{m}$, Anpel Co., Shanghai, China). The filtrate was analyzed for $\mathrm{COD}$ and nitrogen speciation, i.e., nitrate $\left(\mathrm{NO}_{3}{ }^{-} \mathrm{N}\right)$, nitrite $\left(\mathrm{NO}_{2}^{-}-\mathrm{N}\right)$, and total nitrogen $(\mathrm{TN})$. The $\mathrm{COD}$ was analyzed in accordance with standard methods (APHA/AWWA/WEF 2005). $\mathrm{NO}_{3}{ }^{-} \mathrm{N}$ was detected by the ultraviolet spectrophotometric method (PhotoLab 6600). $\mathrm{NO}_{2}^{-}-\mathrm{N}$ was measured using the $\mathrm{N}$-(1-naphthalene)diaminoethane spectrophotometry method; TN was analyzed by the alkaline potassium persulfate ultraviolet spectrophotometry method.

\section{RESULTS AND DISCUSSION}

\section{SBR Operating Conditions}

Temperature and $\mathrm{pH}$ are significant factors affecting bio-chemical process during wastewater treatment. The variations of water temperature and $\mathrm{pH}$ in the SBR system are shown in Fig.1. Stage I was considered as the acclimation for the denitrification process using returned sludge from MWTP. During this period, the water temperature ranged between $15^{\circ} \mathrm{C}$ to $20^{\circ} \mathrm{C}$, and the $\mathrm{pH}$ was 8.0 to 8.7. In the following Stage II and Stage III, the water temperature declined successively, and it mainly ranged between $10{ }^{\circ} \mathrm{C}$ to $15^{\circ} \mathrm{C}$. Stages II and III were considered as the stages for operating-stabilization and riboflavinresponding in the cold season.

Low temperature below $15^{\circ} \mathrm{C}$ inhibits the denitrification activity and functional gene expression, rapidly lowering the nitrogen removal efficiency (Racys et al. 2018). A common engineering resolution of this issue in cold seasons (such as winter) is to enhance the hydraulic/sludge retention time, or to decrease the nitrogen load rate (Song et al. 2020). Elsewhere, new bioreactors such as the moving bed biofilm reactor (MBBR) and biocharpacked SBR were developed to solve this problem (He et al. 2018; Kowalski et al. 2019). However, these modifications required larger reconstruction cost for scale-up applications. 
After the stabilization, riboflavin $(10 \mathrm{mg} / \mathrm{L})$ was added to the influent at Stage III to assess its promotion on denitrification resisting cold temperature. Notably, $\mathrm{pH}$ slightly decreased after the supplement of riboflavin in Stage III, ranging from 7.5 to 8.0. This decrease would be attributed to the potential sludge fermentation triggered by riboflavin (Huang et al. 2019). Moreover, denitrification was an alkalinity-producing process, which would be repressed when ambient $\mathrm{pH}$ was higher than 8.0, or lower than 6.0 (Lin et al. 2009). Thus, riboflavin played a positive role for denitrification by creating a suitable $\mathrm{pH}$ condition, accelerating the start-up of the SBR operation in cold seasons.

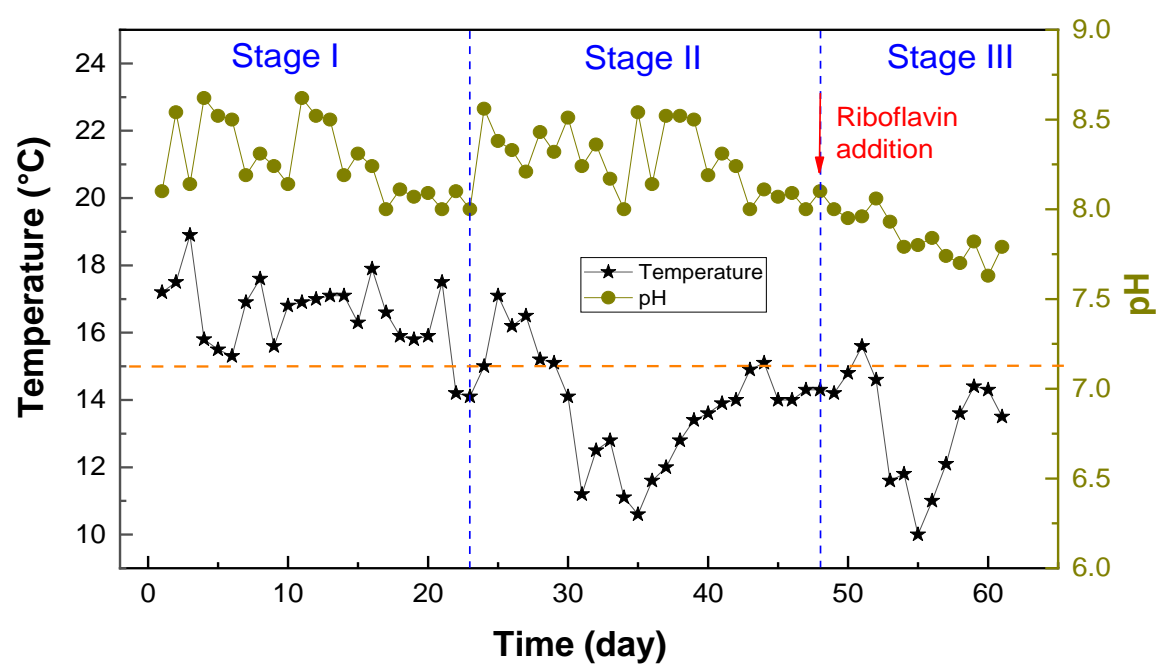

Fig. 1. Variation of water temperature and $\mathrm{pH}$ in different operating stages

\section{Variation of Nitrogen Species in the Effluent}

The concentrations of various nitrogen species, including $\mathrm{NO}_{3}^{-}-\mathrm{N}, \mathrm{NO}_{2}^{-}-\mathrm{N}$ and $\mathrm{TN}$, are shown in Fig. 2. The results indicated a remarkable removal of $\mathrm{NO}_{3}^{-} \mathrm{N}$ after acclimating for six days. In the following Stage II and Stage III, the effluent $\mathrm{NO}_{3}^{-}-\mathrm{N}$ declined to the minimum of $4.5 \mathrm{mg} / \mathrm{L}$ ( $94 \%$ removal). $\mathrm{NO}_{2}{ }^{-}-\mathrm{N}$ showed an increasing trend during Stage I, a slight fluctuation during Stage II, and a tiny decrease during Stage III.

Although $\mathrm{NO}_{3}{ }^{-}-\mathrm{N}$ removal was high, $\mathrm{TN}$ removal was relative lower with $\mathrm{C} / \mathrm{N}$ ratio of 4.0 under low temperature $\left(<15^{\circ} \mathrm{C}\right)$. The results indicated that $\mathrm{NO}_{2}^{-}-\mathrm{N}$ accumulation was gradually increased since the end of Stage I, resulting in a higher effluent TN at $\sim 40$ $\mathrm{mg} / \mathrm{L}$ with removal efficiency below $50 \%$. This occurrence was mainly attributed to the lack of bioavailable electron donor, inducing a partial denitrification of nitrate $\left(\mathrm{NO}_{3}{ }^{-} \mathrm{N}\right)$ to nitrite $\left(\mathrm{NO}_{2}^{-}-\mathrm{N}\right)$ rather than complete denitrification to nitrogen gas $\left(\mathrm{N}_{2}\right)$. Higher $\mathrm{pH}$ promotes the partial denitrification process during the long-term operation (Qian et al. 2019). In this study, higher $\mathrm{pH}$ (8.0 to 8.7) in Stage II was observed (Fig.1), which in turn resulted in a larger $\mathrm{NO}_{2}^{-}-\mathrm{N}$ accumulation. During Stage III, effluent TN was strikingly decreased after the addition of riboflavin $(10 \mathrm{mg} / \mathrm{L})$. In this condition, nitrite concentration was comparable as that in Stage II, while TN removal achieved by up to $70 \%$, much higher than that in Stage II $(<50 \%)$. Notably, the removed TN was not balanced by the produced nitrate and nitrite. This could be attributed to the potential abiotic oxidation of nitrite to nitrate in the presence of riboflavin after the analysis of nitrite (Doane 2017), resulting in a doubled contribution to TN. The exact mechanism needs a further investigation.

Furthermore, the denitrification rate at the end of Stage II (Day 47) was $1.88 \mathrm{mg}$ $\mathrm{NO}_{3}{ }^{-} \mathrm{N} /(\mathrm{L} \cdot \mathrm{h})$, which was increased to $2.19 \mathrm{mg} \mathrm{NO}^{-}-\mathrm{N} /(\mathrm{L} \cdot \mathrm{h})$ at the end of Stage III (Day 
61). The TN removal rate was increased from $1.02 \mathrm{mg} \mathrm{TN} /(\mathrm{L} \cdot \mathrm{h})$ to $1.54 \mathrm{mg} \mathrm{TN} /(\mathrm{L} \cdot \mathrm{h})$. Riboflavin increased $\mathrm{NO}_{3}{ }^{-}-\mathrm{N}$ and $\mathrm{TN}$ removal rate by $16.5 \%$ and $51 \%$, respectively. This result was consistent with those of a previous study, which indicated that artificial electron mediators of AQDS, LAW and NQS could improve the denitrification efficiency by $11 \%$ to $18.7 \%$ under low water temperature condition $\left(10^{\circ} \mathrm{C}\right.$ to $15^{\circ} \mathrm{C}$ ) (Yuan et al. 2017).

As a biogenic and eco-friendly electron mediator, riboflavin could stimulate the denitrification rate and TN removal under low water temperature $\left(10{ }^{\circ} \mathrm{C}\right.$ to $\left.15^{\circ} \mathrm{C}\right)$ in cold season. However, $\mathrm{NO}_{3}{ }^{-}-\mathrm{N}$ and the generated $\mathrm{NO}_{2}^{-}-\mathrm{N}$ were unable to be completely reduced because of the insufficient energy pool (low $\mathrm{C} / \mathrm{N}$ ratio) in this study. High and efficient electron sink to denitrification with limited carbon source is recommended for future studies.

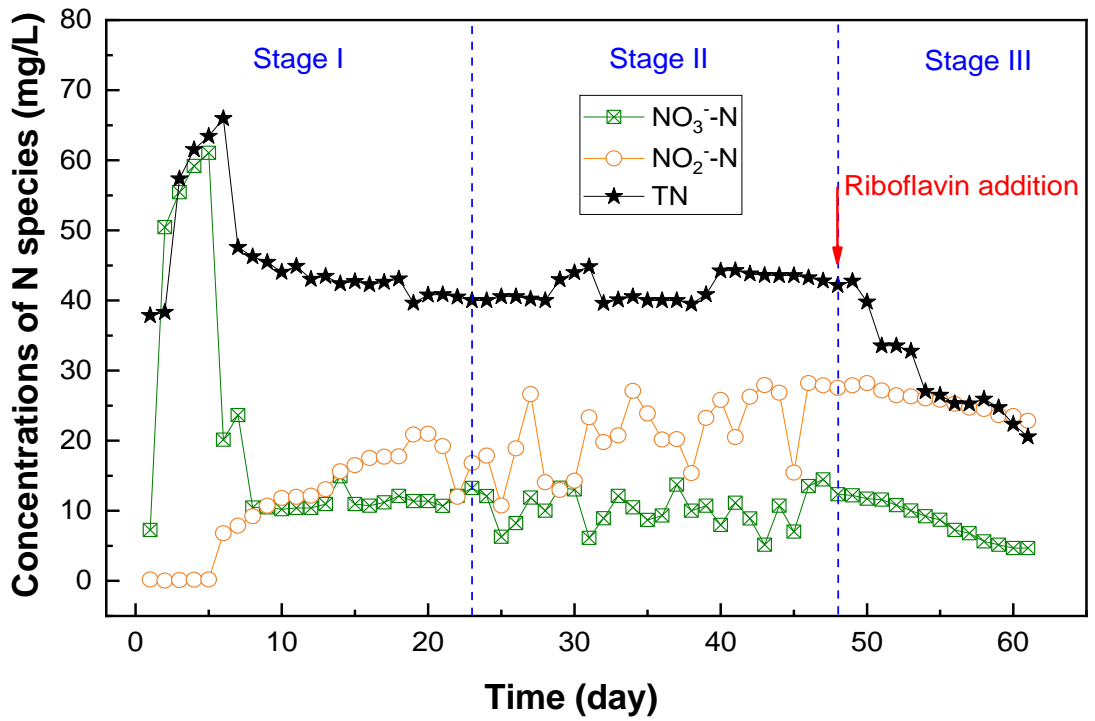

Fig. 2. Variation of $\mathrm{NO}_{3}-\mathrm{N}, \mathrm{NO}_{2}-\mathrm{N}$ and $\mathrm{TN}$ in the effluent at different operating stages

\section{Variation of COD in the Effluent}

Effluent COD concentrations was detected to investigate whether riboflavin could improve the utilization efficiency of limited carbon source, i.e., sodium acetate (Fig. 3).

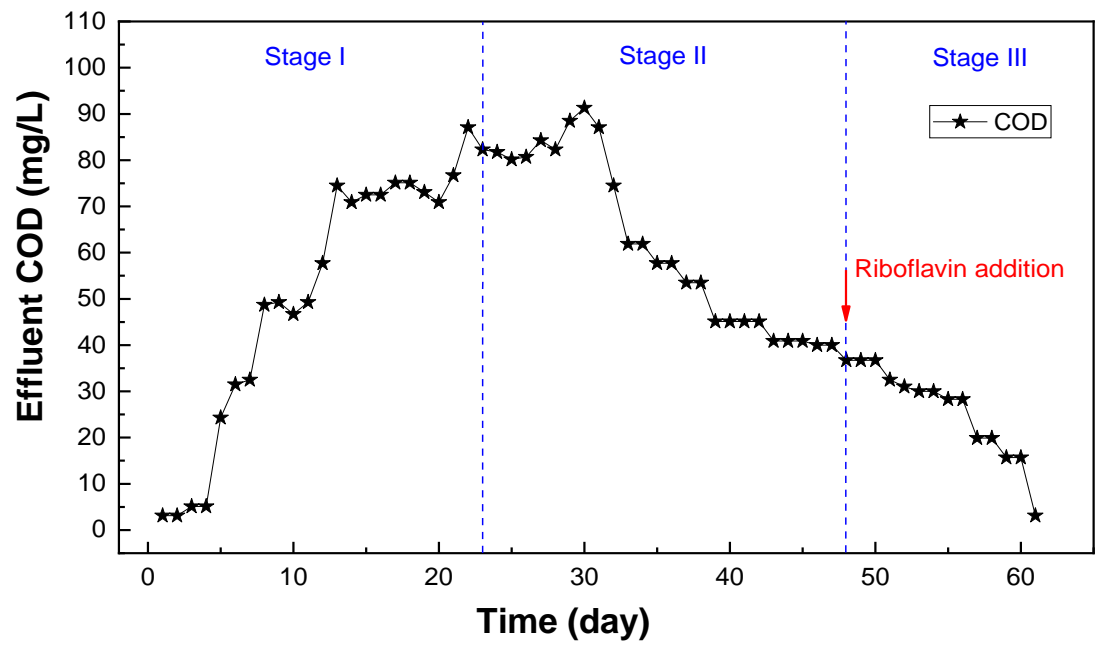

Fig. 3. Variation of COD in the effluent at different operating stages 
During Stage I, the effluent COD was gradually increased to $\sim 80 \mathrm{mg} / \mathrm{L}$, indicating a declined consumption of carbon source in acclimation period. The authors attributed this occurrence to the high $\mathrm{pH}$ and decreased water temperature along with the operation time (Fig. 1), which is not ready for the denitrification gene expression yet (Saleh-Lakha et al. 2009). Furthermore, riboflavin might promote the sludge fermentation to generate soluble organics, which also contributed to the upward trend of effluent COD (Huang et al. 2019).

During Stage II, effluent COD dropped (Fig. 3), indicating a stronger denitrification activity, which in turn consumed more carbon source. At the end of Stage II, effluent COD was stabilized at $\sim 40 \mathrm{mg} / \mathrm{L}$. This low carbon source concentration could hardly drive the denitrification process further, due to the kinetic disadvantage. Notably, after the addition of riboflavin in Stage III, effluent COD first slightly but then sharply declined to undetectable level at the end of Stage III (Day 61). These findings implied that riboflavin could efficiently lower the $E_{\mathrm{a}}$, promoting the effectiveness of residual acetate and potential fermentative by-products as electron donors for denitrification. However, the low $\mathrm{C} / \mathrm{N}$ ratio in this study lacked sufficient energy to drive complete denitrification. Thus, TN could not be further removed to satisfy the Class 1A discharge standard according to Chinese national standard (GB18918-2002).

\section{Operational Cost and Future work}

Efficient nitrogen removal under low $\mathrm{C} / \mathrm{N}$ condition in cold season is an arduous task and an ongoing topic. In this study, the cost of riboflavin addition $(10 \mathrm{mg} / \mathrm{L})$ was calculated at 0.025 USD per $\mathrm{m}^{3}$ of wastewater, based on the industrial riboflavin price of $2.5 \mathrm{USD} / \mathrm{kg}$ (Shi et al. 2020). This would raise the operating cost by $\sim 20 \%$ for municipal wastewater treatment (Qi et al. 2020). In the future, research should be focused on the following: (1) the optimum dosage of added riboflavin should be optimized to reduce the increase in costs; (2) the selection of cheap solid materials with electron mediating ability are highly appreciated to replace soluble redox mediators; (3) the immobilization of soluble redox mediators on special carriers are expected to be developed.

\section{CONCLUSIONS}

1. Riboflavin decreased the $\mathrm{pH}$ to the range 7.5 to 8.0 in the SBR system, which was suitable for the denitrification process, accelerating the start-up of the SBR operation in cold season.

2. Under low water temperature $\left(10{ }^{\circ} \mathrm{C}\right.$ to $\left.15^{\circ} \mathrm{C}\right)$, riboflavin stimulated $\mathrm{NO}_{3}{ }^{-} \mathrm{N}$ and $\mathrm{TN}$ removal by $16.5 \%$ and $51 \%$, respectively; $\mathrm{TN}$ removal was lower than $\mathrm{NO}_{3}{ }^{-}-\mathrm{N}$ due to the partial denitrification and larger accumulation of $\mathrm{NO}_{2}^{-}-\mathrm{N}$.

3. Under low $\mathrm{C} / \mathrm{N}$ ratio (4.0), riboflavin promoted the utilization of limited carbon source, driving the denitrification process with low residual acetate as electron donor.

4. Riboflavin was judged to be a relative cheap electron mediator for denitrification, and the rising cost of its addition $(10 \mathrm{mg} / \mathrm{L})$ was calculated as $0.025 \mathrm{USD}$ per $\mathrm{m}^{3}$ of wastewater. 


\section{ACKNOWLEDGMENTS}

The authors are grateful for the support of the China Postdoctoral Science Foundation (2018M642349) and the Basic scientific research funding of provincial universities in Zhejiang Province, China (GK209907299001-308).

\section{REFERENCES CITED}

APHA/AWWA/WEF (2005). Standard Methods for the Examination of Water and Wastewater (21 ${ }^{\text {st }}$ Ed.), Washington, DC, USA.

Cadena Ramírez, A., Texier, A.-C., Martínez, I. G., and Hernández, J. G. (2019). "Inhibitory effects of quinoid redox mediators on a denitrifying culture," Environ. Technol. 40(10), 1306-1315. DOI: 10.1080/09593330.2017.1421264

Doane, T. A. (2017). "The abiotic nitrogen cycle," ACS Earth Space Chem. 1(7), 411421. DOI: $10.1021 / \mathrm{ac} 050528 \mathrm{~s}$

Elefsiniotis, P., and Li, D. (2006). "The effect of temperature and carbon source on denitrification using volatile fatty acids," Biochem. Eng. J. 28(2), 148-155. DOI: 10.1016/j.bej.2005.10.004

Ge, S., Peng, Y., Wang, S., Lu, C., Cao, X., and Zhu, Y. (2012). "Nitrite accumulation under constant temperature in anoxic denitrification process: The effects of carbon sources and COD/NO3-N," Bioresource Technol. 114, 137-143. DOI: 10.1016/j.biortech.2012.03.016

Guo, H., Chen, Z., Guo, J., Lu, C., Song, Y., Han, Y., Li, H., and Hou, Y. (2019). "Enhanced denitrification performance and biocatalysis mechanisms of polyoxometalates as environmentally-friendly inorganic redox mediators," Bioresource Technol. 291, 121816. DOI: 10.1016/j.biortech.2019.121816

Guo, J., Lian, J., Guo, Y., Liu, X., Zhang, C., Yue, L., and Wang, Y. (2015). “Redox activity and accelerating capacity of model redox mediators during biodenitrification," Biotechnol. Biotec. Eq. 29(4), 673-679. DOI: 10.1080/13102818.2015.1027504

He, S., Ding, L., Pan, Y., Hu, H., Ye, L., and Ren, H. (2018). "Nitrogen loading effects on nitrification and denitrification with functional gene quantity/transcription analysis in biochar packed reactors at $5{ }^{\circ} \mathrm{C}$," Sci. Rep-UK, 8, Article ID 9844. DOI: 10.1038/s41598-018-28305-0

Heylen, K., Vanparys, B., Wittebolle, L., Verstraete, W., Boon, N., and De Vos, P. (2006). "Cultivation of denitrifying bacteria: Optimization of isolation conditions and diversity study," Appl. Environ. Microb. 72(4), 2637-2643. DOI: 10.1128/AEM.72.4.2637-2643.2006

Huang, J., Guo, K., Shi, B., Han, W., Hou, P., and Tang, J. (2020). “Achieving high volatile fatty acid production from raw Henna (Lawsonia inermis) biomass at mild alkaline conditions," BioResources 15(2), 3707-3716. DOI:

10.15376/biores. 15.2.3707-3716

Huang, J., Chen, S., Wu, W., Chen, H., Guo, K., Tang, J., and Li, J. (2019). "Insights into redox mediator supplementation on enhanced volatile fatty acids production from waste activated sludge," Environ. Sci. Pollut. R. 26(26), 27052-27062. DOI:

10.1007/s11356-019-05927-z 
Kowalski, M. S., Devlin, T.R., di Biase, A., and Oleszkiewicz, J. A. (2019). "Controlling cold temperature partial nitritation in moving bed biofilm reactor," Chemosphere, 227, 216-224. DOI: 10.1016/j.chemosphere.2019.04.025

Liang, Y., Li, D., Zhang, X., Zeng, H., Yang, Z., and Zhang, J. (2014). “Microbial characteristics and nitrogen removal of simultaneous partial nitrification, anammox and denitrification (SNAD) process treating low $\mathrm{C} / \mathrm{N}$ ratio sewage," Bioresource Technol. 169, 103-109. DOI: 10.1016/j.biortech.2014.06.064

Lin, Y. M., Tay, J. H., Liu, Y., and Hung, Y. T. (2009). "Biological nitrification and denitrification processes," in: Biological treatment processes, Springer, pp. 539-588.

Lu, C., Xie, Z., Guo, J., Song, Y., Xing, Y., Han, Y., Li, H., and Hou, Y. (2020). "Chlorophyll as natural redox mediators for the denitrification process," Int. Biodeter. Biodegr. 148, Article ID 104895. DOI: 10.1016/j.ibiod.2020.104895

Mielcarek, A., Rodziewicz, J., Janczukowicz, W., and Struk-Sokołowska, J. (2020). “The impact of biodegradable carbon sources on nutrients removal in post-denitrification biofilm reactors," Sci. Total Environ. 720, 137377. DOI:

10.1016/j.scitotenv.2020.137377

Oh, S.-Y., Seo, Y.-D., Kim, B., Kim, I. Y., and Cha, D. K. (2016). "Microbial reduction of nitrate in the presence of zero-valent iron and biochar," Bioresource Technol. 200, 891-896. DOI: 10.1016/j.biortech.2015.11.021

Qi, M., Yang, Y., Zhang, X., Zhang, X., Wang, M., Zhang, W., Lu, X., and Tong, Y. (2020). "Pollution reduction and operating cost analysis of municipal wastewater treatment in China and implication for future wastewater management," J. Clean. Prod. 253, Article ID 120003. DOI: 10.1016/j.jclepro.2020.120003

Qian, W., Ma, B., Li, X., Zhang, Q., and Peng, Y. (2019). "Long-term effect of pH on denitrification: High $\mathrm{pH}$ benefits achieving partial-denitrification," Bioresource Technol. 278, 444-449. DOI: 10.1016/j.biortech.2019.01.105

Racys, V., Dapkiene, M., Bikulciene, L., Jankunaite, D., and Vaiciukyniene, D. (2018). "Effect of external carbon source on municipal wastewater at low temperatures," Water, Air Soil Poll. 229(6), 210. DOI: 10.1007/s11270-018-3812-3

Revuelta, J. L., Ledesma-Amaro, R., Lozano-Martinez, P., Díaz-Fernández, D., Buey, R. M., and Jiménez, A. (2017). "Bioproduction of riboflavin: A bright yellow history," J. Ind. Microbiol. Biot. 44(4-5), 659-665. DOI: 10.1007/s10295-016-1842-7

Saleh-Lakha, S., Shannon, K. E., Henderson, S. L., Goyer, C., Trevors, J. T., Zebarth, B. J., and Burton, D. L. (2009). "Effect of $\mathrm{pH}$ and temperature on denitrification gene expression and activity in Pseudomonas mandelii," Appl. Environ. Microb. 75(12), 3903-3911. DOI: 10.1128/AEM.00080-09

Shi, B., Huang, J., Yin, Z., Han, W., Qiu, S., Tang, J., and Hou, P. (2020). "Riboflavin boosts fermentative valeric acid generation from waste activated sludge," BioResources 15(2), 3962-3969. DOI: 10.15376/biores.15.2.3962-3969

Song, X., Yang, X., Hallerman, E., Jiang, Y., and Huang, Z. (2020). "Effects of hydraulic retention time and influent nitrate- $\mathrm{N}$ concentration on nitrogen removal and the microbial community of an aerobic denitrification reactor treating recirculating marine aquaculture system effluent," Water 12(3), 650. DOI: 10.3390/w12030650

Van der Zee, F. P., and Cervantes, F. J. (2009). "Impact and application of electron shuttles on the redox (bio) transformation of contaminants: a review," Biotechnol. Adv. 27(3), 256-277. DOI: 10.1016/j.biotechadv.2009.01.004

Wu, Z., Xu, F., Yang, C., Su, X., Guo, F., Xu, Q., Peng, G., He, Q., and Chen, Y. (2019). "Highly efficient nitrate removal in a heterotrophic denitrification system amended 
with redox-active biochar: a molecular and electrochemical mechanism," Bioresource Technol. 275, 297-306. DOI: 10.1016/j.biortech.2018.12.058

Yuan, H., Sun, Y., Sun, J., Wang, X., and Yuan, J. (2017). "Improvement in denitrification efficiency at low temperature with addition of redox mediators," Desalin. Water Treat. 81(6), 80-86. DOI: 10.5004/dwt.2017.21088

Zhang, L., Song, Y., Zuo, Y., Huo, S., Liang, C., and Hu, C. (2019). "Integrated sulfurand iron-based autotrophic denitrification process and microbial profiling in an anoxic fluidized-bed membrane bioreactor," Chemosphere 221, 375-382. DOI: 10.1016/j.chemosphere.2018.12.168

Article submitted: September 21, 2020; Peer review completed: December 19, 2020; Revised version received and accepted: January 25, 2021; Published: January 26, 2021. DOI: 10.15376/biores.16.1.1949-1957 